\title{
Renewal of The Elements of Success On Al-Qurán Memorization Program During Covid-19 Pandemic
}

\author{
*Emmilia Rusdiana ${ }^{1}$, Nurul Hikmah ${ }^{2}$ \\ ${ }^{1,2,3}$ Universitas Negeri Surabaya (UNESA), Jl. Lidah Wetan, Kota Surabaya, Indonesia \\ *emmiliarusdiana@unesa.ac.id
}

\begin{abstract}
An effective way to prevent the spread of the Corona virus is to force the pesantren students to return home which has the Tanfidz program. memorizing Al-Qurán. The obstacle is the ban face to face between students and teachers tanfidh. The use of technology information allows the learning model tahfizh from their homes by the method of use of communication in the network. The purpose was to analyze the renewal of the success elements of Islamic boarding school students in increasing the memorization of Al Qurán during the COVID 19 pandemic. This research uses approaches to Analyze, Design, Develop, Implement, and Evaluate ADDIE. The discussion shows that the root problems are motivation and memorization decrease and the solution are informal communication with others and reducing a busy school that is not important. The success element is influenced by enthusiasm/motivation and the method when memorizing and communication on the Al-Qurán memorization. The highest motivation is when students are accompanied by friends or family and informal communication with other people to always increase their commitment, then using the right method is the easiest to use. Meanwhile, the appropriate online communication method to be applied is synchronous than asynchronous communication. A choicen Platform is video call whatsApp than voicecall whatsapp or zoom/goole meet and it conducts for both, individually or in groups.
\end{abstract}

Cara yang efektif untuk mencegah penyebaran virus Corona adalah dengan memaksa santri pesantren untuk pulang kampung yang memiliki program Tanfidz. menghafal Al-Qur'an. Hambatannya adalah larangan tatap muka antara siswa dan guru tanfidh. Penggunaan teknologi informasi memungkinkan adanya model pembelajaran tahfizh dari rumah dengan metode penggunaan komunikasi dalam jaringan. Tujuannya adalah untuk menganalisis pembaharuan unsur keberhasilan santri dalam meningkatkan hafalan Alquran pada saat pandemi COVID 19. Penelitian ini menggunakan pendekatan Analyze, Design, Develop, Implement, dan Evaluate ADDIE. Hasil pembahasan menunjukkan bahwa akar permasalahannya adalah berkurangnya motivasi dan hafalan serta solusinya adalah komunikasi informal dengan sesama dan mengurangi kesibukan sekolah yang tidak penting. Unsur keberhasilan dipengaruhi oleh semangat / motivasi dan cara menghafal dan komunikasi dalam menghafal Al-Qur'an. Motivasi tertinggi adalah ketika siswa didampingi oleh teman atau keluarga dan komunikasi informal dengan orang lain untuk selalu meningkatkan komitmennya, maka metode yang tepat adalah yang paling mudah digunakan. Sedangkan metode komunikasi online yang tepat untuk diterapkan adalah sinkronis 
daripada komunikasi asinkron. Platform pilihan adalah video call whatsApp daripada panggilan suara whatsapp atau zoom / goole meet dan itu dilakukan untuk keduanya, secara individu atau dalam kelompok.

Keywords: Islamic boarding schools, memorizing Al-Quran, online communication, Covid-19 Pandemic.

Received: January 10, 2021; Revised: Maret 13, 2021; Accepted: April 23, 2021

\section{INTRODUCTION}

Testimony given by Muslims is the existence of creed, apart from witnessing the existence of Allah SWT and the Muhammad SAW as messengers of Allah SWT, it is to serve as evidence for the exemplary testimony of Prophet Muhammad SAW. Rasulullah SAW a role model by memorizing the Qur'an, and every month of Ramadan Jibril comes to him to check his memorization. It is narrated by Ibn Abbas;

"Muhammad SAW is the most generous person. And he was even more generous in the month of Ramadan when he met Jibril. Jibril met him every night to teach the Qur'an. And the generosity of the Prophet sallallaahu 'alaihi wa sallam exceeds the wind that blows". Narrated by Bukhari, No. 6.

The world's attention regarding the new virus that attacks the respiratory tract, namely the COVID-19 virus. WHO's an assessment of the threat posed by the Corona COVID-19 Virus also does not change what WHO is doing and countries should do. Tedros Adhranom The Breyesus (Hatta, 2019) said that WHO asks all countries to strike a good balance between protecting health, minimizing economic and social disruption, and respecting human rights amid this pandemic. This is not just a public health crisis, it is a crisis that will impact every sector, while urging every sector and individual to engage in the global fight against COVID-19.

Andri (Izzanam, 2019) said that psychosomatic disorders also occur when you read news about the corona virus or COVID-19, then feel pain according to the symptoms, even though your body is in a normal condition. Psychosomatic there; ah to describe a physical illness caused by a person's psychological condition.

One comprehensive solution is to carry out prevention and cure of COVID-19 by reading Al-Qur'an while Al-Qur'an is a remedy for liver disease and physical ailments. Allah Ta'ala said:

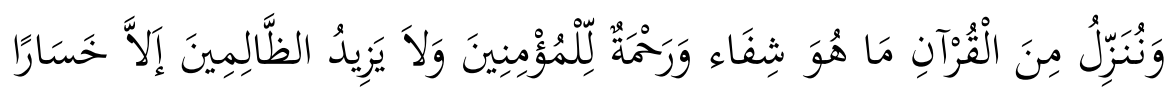

"And We send down from the Qur'an something that is an antidote and a mercy for those who believe and the Qur'an does not add to the wrongdoers other than harm".(QS. al-Isra':82)

A pretty effective way to prevent the spread of the Corona virus is to repatriate the student's boarding school pondok pesantren, including a boarding school that focuses on tanfidh program memorizing Al-Qurán. One of the obstacles is that it is not possible to meet face to face with the ustad/ustadzah or reciting teacher, while information technology continues to develop and the hope is the realization of the element of success in memorizing. 
This shows the need for an alternative implementation of this program as a development of the tanfidz program involving technology, namely the learning model of the tahfizh program at the home of each student with guidance that involves technological means.

Given that attitudes towards learning have increased, self-esteem, and desire to develop also increased. Cotton (Cotton, 2005) concluded that the results of research on computer-assisted learning if the computer is linked as part of learning, then this computer-assisted learning increases the acquisition of higher learning outcomes. Meanwhile, Dabbagh \& Bannan-Ritland (Dabbagh, N. \& Bannan-Ritland, 2005) Define, "online learning is an open and distributed learning environment that uses pedagogical tools, enabled by the internet and web-based technologies, to facilitate learning and knowledge building through meaningful action and interaction".

Specifically, e-learning according to Clark \& Mayer (Clark, R.C., \& Mayer, 2015) is defined as follows. Instruction delivered on a computer by way of CD-ROM, internet, or intranet with the following features: 1 includes content relevant to the learning objectives, 2 uses instructional methods such as examples and practice to help learning, 3 uses media elements such as words and pictures to deliver the content and methods, and 4 builds new knowledge and skills linked to individual learning goals or to improve organizational performance. Based on the above limitations, it follows that learning through this online network system includes four important things. The four things are as follows: 1 the content presented has relevance to the specific learning objectives to be achieved, 2 uses learning methods through examples and exercises to help to learn, 3 uses media such as pictures - pictures and words to present content and methods, and 4 developing and building new knowledge and skills according to individual and organizational improvement goals.

The substance referred to here is the material in the form of memorizing the Al-Quran to keep memorization intact and there are still activities in the form of murojaah, using memorization methods and methods of mentoring with teachers who are not in one place, and at the same time building knowledge of existing technology-based tools.

In improving the ability to read Al-Qurán, it is necessary to have the right method so that the ability to read $\mathrm{Al}$ Qurán can increase. A method is a term used to express the meaning of "The most appropriate and fast way of doing something, namely a way that functions as a tool to achieve goals. The better the method, the more effective the achievement of goals, thus the goal is the main factor in determining whether or not the use of a method is good, while to master Al-Qurán properly, one must master the makharijul letters and understand tajwid well (Wahid, 2014).

Based on the results of preliminary observations on several tanfidz santri at several Islamic boarding schools, namely the An-Nur Islamic boarding school in Surabaya, the Amanatul Ummah Islamic Boarding School in Surabaya, the following are various methods of memorizing Al Qurán that has been applied in several Islamic boarding schools which are held face-to-face advance (Zahra, 2019).

The difference between the three can be illustrated that the tikrar method (Khoiriyah, $2005)$ is double repetition and depositing rote memorization to the teacher. The talqin method is applied by the teacher dictating the recitation of Al Qurán and the students follow. If the student's reading is correct, they are given the task of memorizing the reading and depositing it. The key is persistence in doing it, This method is called being able to memorize Al Qurán without memorizing it. Performed with Reps or 
Repetition. The trick is to read the verse over and over again. until we are trained to utter spoken verse in memorize. Repetition of reading up to at least 40 times, so that the verse we memorize will be stronger embedded in the mind. Besides that, our speech is also getting easier to pronounce. Tikrar means to repeat the reading until it is memorized. Then Muraja'ah, after memorizing it, repeated the recitation. Muraja'ah is very important because it is muraja'ah that will attach rote memorization more strongly into our minds. Imam al-Bukhari also shared secrets about the power of his memorization.

The second method most often used is the method of memorizing the name without a method (Wahyu Eko Hariyanti, 2019) is memorizing Al Qurán in five ways: read over and over, heard over and over, understood over and over, written over and over again and deposited by rote over and over again, while the third method is the 3T \& $1 \mathrm{M}$ (M. Shohibul Mujtaba, 2019) method Talqin, Tasmi, Tafahhum and Murajaah. Talqin means an Ustadz reciting Al Qurán for his students to follow. As for tasmi ', it means that a student reads Al Qurán for the ustadz to listen to. Tafahhum, is understanding the meaning of the recitation of $\mathrm{Al}$ Qurán that will be memorized. Of course, not everyone has to go through this stage in memorizing. Those who are advised to understand $\mathrm{Al}$ Qurán while memorizing is those who are teenagers and adults.

All activities in memorizing and memorizing in the face of the Covid-19 pandemic will be arranged using the following online communication methods. Communication methods are divided into face-to-face offline methods and online methods. Meanwhile, online communication is divided into two types, namely: a Synchronous communication: is communication carried out at the same time real-time and using an intermediary media in the form of a computer or smartphone, and b. Asynchronous communication: is a type of communication that takes place at different times.

Types of online communication that are often used in everyday life:

1. Synchronous Communication Chat, communication is for using written messages sent to the interlocutor. In the form of talking chatting with a platform that provides chat communication services that can be used on smartphones and computers, with other types of chat applications including WhatsApp, Line Chat, telegram or SMS.

2. Call synchronous communication, the user uses an application installed on a smartphone connected to the internet. This method of communicating does not use credit or telephone bills, but rather internet quota.

3. Video Call Synchronous Communication, this communication uses a video call as a liaison. The other person can be seen through a computer or smartphone screen or face to face.

4. Video Asynchronous Communication, communication by sharing video recordings with the other person. And can't see directly the person's condition.

5. Asynchronous Communication Chat, asynchronous communication chat allows users to share short messages using the existing platform options. It's just that the type of communication that exists is delayed communication.

6. Group Communication, this communication is done in groups and can take the form of a platform. Group communication makes it easy to disseminate information specific to a group. 
7. Formal Communication, online communication is done during formal events official. Its purpose is to convey information related to an interest. For example, a video conference, or a meeting.

8. Non-formal communication, communication can occur in formal or informal events. When done at formal events, this type of communication is more personal.

9. Informal communication, this communication aims to maintain social relationships. The message or chat that was sent was not planned.

Based on memorization methods and communication methods that are associated with the motivation of students in keeping their memorization during the pandemic of Covid-19, this research aims at:

1. Increased consistency and motivation of students in memorizing Al-Qurán to prevent COVID 19.

2. Describe the elements of successful online communication in connection with the increase in the memorization of Al-Qurán during COVID 19.

\section{METHOD}

This research uses approaches to Analyze, Design, Develop, Implement, and Evaluate ADDIE.

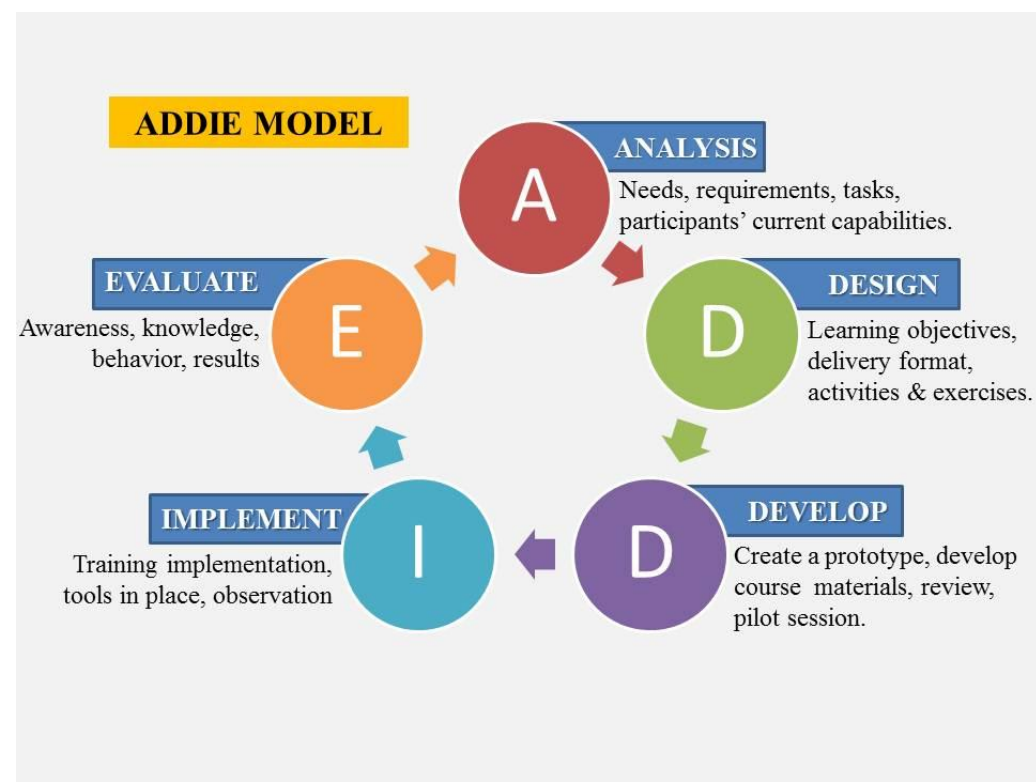

The purpose of Analyze is "to identify the probable causes for a performance gap". Then the purpose of the design is to verify the desired performances and appropriate testing methods, the Develop phase is to generate and validate the learning resources that will be required during the life of the instructional modules, the purpose of the Implement phase is to prepare the learning environment and engage the students. The purpose of the Evaluate phase is to assess the quality of the instructional products and processes, both before and after implementation (Branch, 2009).

The purpose of the analysis is to identify the causes of the problems faced by the researcher. From these problems, the design is an effort that will be made to overcome the problem. The next step is development to ensure and validate the method that will 
be used, after validation the method will be applied to online learning and see the effects of this application, and the final step is to evaluate the method. Based on the data obtained from the research instrument, then it was analyzed descriptively qualitatively.

The data analysis technique used descriptive qualitative. The data collected were analyzed qualitatively, basically this analysis is based on simplification and interpretation of data. This process consists of three sub-processes of analysis, namely data presentation, data reduction, and verification, which can be described as follows (Miles, 1992). The components in this analysis are not carried out separately, but are a continuous and related process until a conclusion is obtained.

\section{RESULT AND DISCUSSION}

This study involved 17 students who memorized the Al-Qur'an who were in their homes and were sent home by their respective Islamic boarding schools due to the COVID-19 pandemic starting at the end of March 2020 (Ikhwan, 2017). The students had memorized activities and at the same time conducted Al-Qurán memorization murojaah with the face-to-face method, while this research emphasizes the use of online communication methods because of the prohibition of face-to-face contact with spiritual teachers/teachers. The following is the profile of students by age:

Tabel 1. the profile of students by age

\begin{tabular}{|c|c|c|}
\hline No. & Based on Age & Person \\
\hline 1 & $16-18$ years & 6 \\
\hline 2 & $19-20$ years & 7 \\
\hline 3 & $21-22$ years & 4 \\
\hline & \multicolumn{2}{|c|}{ Total } \\
\hline
\end{tabular}

Some of the students are currently in higher education college and some are graduating from public high school and are in Islamic boarding schools while studying. The following is the distribution of the profile of the students based on gender:

Tabel 2. the students based on gender

\begin{tabular}{|c|c|c|}
\hline No. & Gender & Person \\
\hline 1 & Male & 2 \\
\hline 2 & Female & 15 \\
\hline & \multicolumn{2}{|c|}{ Total } \\
\hline
\end{tabular}

This gender profile shows that women dominate more than men to form a new group at the time of the Covid-19 pandemic. The following is the origin of the santri boarding school:

Tabel 3. the origin of the santri boarding school 
33 Al-Hayat: Journal of Islamic Education (AJIE)

e-ISSN: 2599-3046 (online) | Volume 5, Issue 1 | January -June 2021

p-ISSN:2657-1781 (print)

\begin{tabular}{|c|l|c|}
\hline No. & \multicolumn{1}{|c|}{ Origin of The Islamic Boarding School } & $\begin{array}{c}\text { Perso } \\
\text { n }\end{array}$ \\
\hline 1 & Ponpes Tahfidzil Qur'an Hidayatul Mubtadi'in & 1 \\
\hline 2 & Pondok Pesantren Madrasatul Quran & 1 \\
\hline 3 & Al Ikhlas Bahrul Ulum Tambak Beras Jombang & 4 \\
\hline 4 & Pondok Pesantren Putri Walisongo Cukir Tebuireng Jombang & 5 \\
\hline 5 & Pondok Pesantren Dr. H. Moeldoko & 1 \\
\hline 6 & Ponpes. As-Syafi' Iyah Tanggulangin-Sidoarjo & 2 \\
\hline 7 & PP. Imam Bukhory & 1 \\
\hline 8 & Pondok Pesantren Al-Amien Prenduan Sumenep Madura & 1 \\
\hline 9 & Al-Islah Lebak, Sumurgung, Montong, Tuban & 1 \\
\hline & Total & 17 \\
\hline
\end{tabular}

Most of the santri is currently studying at the Madrasah Aliyah level or studying higher education at PT. while also carrying out activities in the boarding school. The Islamic boarding school program which has a tahfidz memorizing Al-Qurán program, will hold activities in the form of an Al-Qurán memorization program (Ikhwan, Anwar and Mahmudah, 2021). The duration the students have held Al-Qurán memorization activities until September 2020 are as follows:

Tabel 4. The duration the students have held Al-Qurán memorization

\begin{tabular}{|c|c|c|}
\hline No. & \multicolumn{1}{|c|}{ Duration } & Person \\
\hline 1 & Over 5 years & 2 \\
\hline 2 & 5 years & 3 \\
\hline 3 & 4 years & 3 \\
\hline 4 & $2-3$ years & 6 \\
\hline 5 & 1 year & 3 \\
\hline & \multicolumn{2}{r}{ Total } \\
\hline
\end{tabular}

The selected students are those who have been in the tahfidz program for at least 2 years, because 2 years is the time that is considered sufficient to find out someone's commitment to activities, and this continues in the context of motivation and various memorization methods of communication methods. The ages of the students when starting to memorize Al Qurán are as follows: 
Tabe 5. The ages of the students when starting to memorize

\begin{tabular}{|c|c|c|}
\hline No. & The Starting Time & Person \\
\hline 1 & 4-6 years & 2 \\
\hline 2 & $8-10$ years & 4 \\
\hline 3 & 12 years & 3 \\
\hline 4 & 13 years & 3 \\
\hline 5 & 16 years & 17 \\
\hline & & Total
\end{tabular}

The age of the students is very important to assess a person's commitment or motivation as well as to determine the experience in memorizing activities. The design and development stage of the research is to design a schedule with a research tutor by selecting the type of platform in online communication:

Tabel 6. platform in online communication

\begin{tabular}{|c|l|c|}
\hline No. & \multicolumn{1}{|c|}{ Type of Online Communication } & Platform Form \\
\hline 1 & Synchronous synchronous/real time & $\begin{array}{c}\text { Whatsapp video call, Whatsapp voice } \\
\text { call, Zoom, Google meet }\end{array}$ \\
\hline 2 & Asynchronous not synchronous & Whatsapp voice note, SMS \\
\hline
\end{tabular}

Develop using online communication methods in the form of synchronous and asynchronous. This is done by holding activities by determining the schedule based on each group and the need for platform trials:

Tabel 7. the schedule based on each group and the need for platform trials

\begin{tabular}{|c|l|c|c|}
\hline No. & \multicolumn{1}{|c|}{ Type of Platform } & $\begin{array}{c}\text { Number of } \\
\text { Individual Meetings }\end{array}$ & $\begin{array}{c}\text { Number of Group } \\
\text { Meetings }\end{array}$ \\
\hline 1 & Whatsapp videocall & 5 & 3 \\
\hline 2 & Whatsapp voicenote & 10 & 5 \\
\hline 3 & $\begin{array}{l}\text { Zoom/Google meet } \\
\text { synchronous }\end{array}$ & - & 5 \\
\hline 4 & Whatsapp voice call & 5 & 10 \\
\hline
\end{tabular}

Determination of the number of individual and group meetings based on juz and required data requirements related to motivation and effectiveness of online communication methods. Implementation using several meetings every week for a month and each meeting for 60 minutes is divided into the following table: 
Tabel 8. Implementation using several meetings every week for a month and each meeting

\begin{tabular}{|c|l|l|l|}
\hline No. & \multicolumn{1}{|c|}{ Group Division } & \multicolumn{1}{|c|}{ Rote Material } & \multicolumn{1}{|c|}{ The Duration } \\
\hline 1 & 3 persons & Juz $1-5$ & 30 minutes \\
\hline 2 & 6 persons & $1-10 \mathrm{Juz}$ & 45 minutes \\
\hline 3 & 7 persons & $1-15 \mathrm{Juz}$ & 60 minutes \\
\hline 4 & 1 person & $1-30 \mathrm{Juz}$ & 15 minutes \\
\hline
\end{tabular}

Evaluation is the presence of input from students regarding motivation, memorization methods and online communication methods when memorizing murojaah, so the results of the research are in the form of evaluation results related to memorizing activities and at the same time holding Al-Qurán memorization murojaah with online communication methods during the Covid-19 pandemic.

The study concluded that the components of success for students in memorizing $\mathrm{Al}$ Qurán are influenced by the following factors.

\section{Motivation in Memorizing}

The most motivation for a santri to memorize is that of his own will, then motivation that arises because of parents 'requests, and motivation that comes from activities which are the boarding school program, or a combination of self-will as well as parents' requests.

One of the role models of students in increasing motivation is that the majority give choices to the kiai or bu nyai of the Islamic boarding school which in this case is the caretaker of the boarding school, the next role model is from the parents, then the role model for the ustadzah/ustad namely the santri rote teacher and a combination of spiritual teachers/parents, or from other Al-Qur'an memorizers who are considered to be motivators, such as KH Quraisy Shihab, small children, friends or relatives and others who personally inspire them because of their memorizing ability and consistency of enthusiasm to date.

The following is a table relating to the root of the problem when carrying out memorizing activities and memorizing Al Qurán during the Covid-19 pandemic, which is as follows:

Tabel 9. the problem when carrying out memorizing activities and memorizing

\begin{tabular}{|l|l|l|}
\hline \multicolumn{1}{|c|}{ The Problem } & \multicolumn{1}{c|}{ Obstacle } & \multicolumn{1}{c|}{ Solutions } \\
\hline Motivation & $\begin{array}{l}\text { Management of unstable } \\
\text { motivation }\end{array}$ & $\begin{array}{l}\text { There is informal } \\
\text { communication with } \\
\text { others }\end{array}$ \\
\hline Memorization decreases & School activity agenda dense. & $\begin{array}{l}\text { Reducing a busy school } \\
\text { that is not important }\end{array}$ \\
\hline
\end{tabular}


The domination of santri progress is influenced by the management of motivation with constraints and ways of solving problems. The obstacle that most often arises is the busy school activity agenda and the most important thing is unstable enthusiasm. The efforts of the students to solve the obstacles in the process of memorizing the AlQurán are by reducing other activities, while the majority is by increasing the enthusiasm or intention of the students. One of the efforts to increase motivation is the urgent need for santri to establish informal communication with other people, in this case interacting with the ustadz/ustadzah, or with fellow memorizers and with the Islamic boarding school. Informal communication (Devito, 2011) is communication that is not structured or systematic but is more about personal communication, and this is socially agreed and its orientation is more individual. The following are the advantages and disadvantages of face-to-face offline communication with online communication:

Tabel 10. the advantages and disadvantages of face-to-face offline communication with online communication

\begin{tabular}{|c|l|l|}
\hline & \multicolumn{1}{|c|}{ Face-To-Face } & \multicolumn{1}{c|}{$\begin{array}{c}\text { Communication Online } \\
\text { Communication }\end{array}$} \\
\hline Strengths & Increased motivation & $\begin{array}{l}\text { Memorization activities take } \\
\text { longer }\end{array}$ \\
\hline weaknesses & $\begin{array}{l}\text { A personal commitment } \\
\text { was never discussed }\end{array}$ & $\begin{array}{l}\text { Motivation and commitment } \\
\text { did not increase }\end{array}$ \\
\hline
\end{tabular}

The table above shows that the two communication methods have their respective strengths and weaknesses, and related to motivation is the presence of personal commitment that affects a sustainability of humiliating activities. Face-to-face communication is indeed invincible for increasing the motivation of the santri even though personal commitments are never given special time for individual communication. Meanwhile, online communication is a decrease in motivation even though memorizing activities seem to take longer than with face-to-face communication.

\section{Methods of Memorizing Al-Qur'an}

The method of memorizing the Al-Qur'an that has been used in memorizing Al Qurán is the majority with the tikrar method i.e. from the Pondok Pesantren method, the second is without the method and the last is the $3 \mathrm{~T}$ method and $1 \mathrm{M}$.

The following is information about the reasons for choosing a method of memorizing Al Qurán and choosing another method for certain reasons. Santri chose a method of memorizing based on the boarding school program and some of them had their method self-taught, and most of them did not know what kind of method had been used so far. The knowledge of students about the methods of memorizing Al Qurán is that the majority have never tried to replace it by using another method of memorizing the Qur'an, while there are students who have changed and chose tikrar.

\section{Methods of communication in memorizing murojaah}

The method of communication of students who memorize the Al-Qurán when performing murajaah repetition of recitation in Islamic boarding schools is the 
majority done face-to-face and only a student who undergoes a combination of faceto-face and online. The process of memorizing Al-Qur'an face to face only with ustadzah/ustad and a combination of ustad and peers. Santri argued that the method of communication in memorizing Al-Qurán is important and a small part is normal (Anwar, 2021).

Most of the students concluded that motivation/enthusiasm depends on the choice of a communication method in memorizing face to face or online. Regarding memorization guidance with online communication, it turns out that the majority of students want a group or rote group, then there is a tutor who accompanies, and collaborates with friends.

All Qurán memorizers already have accounts on social media, namely WhatsApp, Instagram and Facebook, and the majority of the students already have a special WhatsApp group for Al-Qurán memorizers, although there are students who do not have a group. This contradicts the knowledge of the santri about the online method, because the majority said they did not know, so the majority of students have never communicated online synchronously simultaneously or online communication asynchronously not simultaneously when memorizing either a video call or Whatsapp voice call, and only one person has used Zoom/Google meet or via whatsapp voice notes, and SMS.

The following is a selection of students showing the weaknesses and strengths of each type of online communication:

Tabel 11. selection of students showing the weaknesses and strengths of each type

\begin{tabular}{|c|c|c|c|}
\hline $\begin{array}{c}\text { Types of } \\
\text { Communication }\end{array}$ & $\begin{array}{l}\text { Types of } \\
\text { Platforms }\end{array}$ & Weaknesses & Advantages \\
\hline \multirow{3}{*}{$\begin{array}{l}\text { Asynchronous } \\
\text { online } \\
\text { communication }\end{array}$} & \multirow{3}{*}{$\begin{array}{l}\text { Voice notes } \\
\text { Whatsapp }\end{array}$} & No monitoring & time is free of \\
\hline & & $\begin{array}{l}\text { response too } \\
\text { long }\end{array}$ & no need for agreement \\
\hline & & Not excited & $\begin{array}{l}\text { Can immediately check } \\
\text { the shortage of students }\end{array}$ \\
\hline \multirow{3}{*}{$\begin{array}{c}\text { Online } \\
\text { communication } \\
\text { synchronous }\end{array}$} & $\begin{array}{l}\text { Voice Call } \\
\text { whatsapp }\end{array}$ & $\begin{array}{l}\text { There must be } \\
\text { an agreement } \\
\text { Faster agenda }\end{array}$ & $\begin{array}{l}\text { - } \quad \text { There is a monitoring } \\
\text { - } \quad \text { stable network } \\
\text { - a cheap internet quota }\end{array}$ \\
\hline & $\begin{array}{l}\text { Video Call } \\
\text { whatsapp }\end{array}$ & $\begin{array}{l}\text { There must be } \\
\text { an agreement }\end{array}$ & $\begin{array}{l}\text { - there is the monitoring } \\
\text { of the fast } \\
\text { implementation } \\
\text { - cheap internet quota. } \\
\text { - Stable network }\end{array}$ \\
\hline & $\begin{array}{l}\text { Zoom/google } \\
\text { meet }\end{array}$ & $\begin{array}{l}\text { - There must } \\
\text { be an } \\
\text { agreement } \\
\text { - Unstable } \\
\text { network } \\
\text { - internet }\end{array}$ & $\begin{array}{l}\text { There is a monitoring } \\
\text { Longer group }\end{array}$ \\
\hline
\end{tabular}




\begin{tabular}{|l|l|l|l|}
\hline & & $\begin{array}{l}\text { quota } \\
\text { wasteful }\end{array}$ & \\
\hline
\end{tabular}

Santri prefers face-to-face offline communication methods when making rote deposits rather than online communication. Santri has the experience of being in a large community to learn to memorize the Al-Qurán together, for example a big conference/meeting/discussion, but during the Covid-19 pandemic, there were absolutely no activities related to increasing the ability to memorize Al-Qurán.

The following is data on the experiences of students regarding the types of online communication related to the motivation obtained:

Tabel 12. data on the experiences of students regarding

\begin{tabular}{|c|c|c|c|c|}
\hline Motivation For & \multicolumn{3}{|c|}{ Whatsapp } & Zoom/Google Meet \\
\hline & voicecall & videocall & voicenote & \\
\hline Group & Spirit & $\begin{array}{c}\text { Very } \\
\text { enthusiastic }\end{array}$ & $\begin{array}{c}\text { Not } \\
\text { enthusiastic }\end{array}$ & Very enthusiastic \\
\hline Individual & spirit & $\begin{array}{c}\text { Very } \\
\text { enthusiastic }\end{array}$ & $\begin{array}{c}\text { Not } \\
\text { enthusiastic }\end{array}$ & \\
\hline
\end{tabular}

Santri prefers memorizing activities with communication in the form of a whatsapp video call platform because they meet in person even though face to face via electronic media but are the main choice because of the important motivation to stay awake and feel like there is a spiritual teacher accompanying.

The facility for students to memorize Al-Qurán by communicating online is that the majority of students have personal electronic devices, namely cellphones gadgets, then some have gadgets and laptops, while other students have their own electronic devices and some borrow from friends. The majority of students also access the internet by buying an internet package and a small portion with public-owned WIFI access.

\section{CONCLUSION}

The results of the research and discussion show that the success element of students memorizing the Al-Qur'an during the Covid-19 pandemic is influenced by the enthusiasm or motivation in memorizing, the method when memorizing Al-Qurán and the method of communication in memorizing the Al-Qurán memorization. The highest motivation is when students are accompanied by friends or family around them when memorizing and there is informal communication with other people to always increase their commitment, then using the right method when memorizing Al-Qurán is the easiest to use. Meanwhile, the right online communication method to be applied is synchronous communication simultaneously via WhatsApp video call individually or in groups because it can increase motivation or enthusiasm in memorizing and the progress of memorization increases when in groups and is accompanied by a spiritual teacher and does not require greater costs and networks. more stable. 
39 Al-Hayat: Journal of Islamic Education (AJIE)

e-ISSN: 2599-3046 (online) | Volume 5, Issue 1 | January -June 2021

p-ISSN:2657-1781 (print)

\section{REFERENCES}

[1] Anwar, S. (2021) 'Internalisasi Nilai Pendidikan Akhlak dalam Surat Al-Hujurat Tafsir fi ZIlalil Qur' an', JIE: Journal of Islamic Edication, 6(1), pp. 1-12.

[2] Branch, R. M. (2009) 'Instructional Design-The ADDIE Approach', Springer,.

[3] Clark, R.C., \& Mayer, R. . (2015) E-Learning and the Science of Instruction. Market Street. San Fransisco.

[4] Cotton, K. (2005) Computer-Assisted Instruction School Improvement Research Series. Portland.

[5] Dabbagh, N. \& Bannan-Ritland, B. (2005) Online Learning. Concept, Strategies, and Application. New Jersey.

[6] Devito, J. A. (2011) Komunikasi antar manusia (translator by Agus Maulana). 5th edn. Jakarta: Karisma Publishing Group.

[7] Hatta, R. T. (2019) Peringatan Keras WHO, (Jakarta: SCTV, 2019)., liputan6.com.

[8] Ikhwan, A. (2017) 'Metode Simulasi Pembelajaran dalam Perspektif Islam', Istawa: Jurnal Pendidikan Islam, 2(2), pp. 1-34. doi: 10.24269/ijpi.v2i2.623.

[9] Ikhwan, A., Anwar, S. and Mahmudah, N. (2021) 'Tahsin and Tahfidz Learning System at Integrated Islamic Elementary School (SDIT) Insan Madani During the Pandemic Covid-19', Al-Hayat: Journal of Islamic Education (AJIE), 4(2), pp. 111.

[10] Izzanam (2019) Merasa Sakit setelah Baca soal COVID-19? 5 Fakta Gangguan Psikosomatike, Merasa Sakit setelah Baca soal COVID-19? 5 Fakta Gangguan Psikosomatik.

[11] Khoiriyah, N. (2005) Metode Menghafal Al-Qur'an Studi Komparasi Pondok Pesantren Sabilul Huda Banyubiru dan Pondok Pesantren Nazzalal Furqon Salatiga. Institut Agama Islam Negeri Salatiga.

[12] M. Shohibul Mujtaba, M. A. (2019) 'Cara Menghafal Al-Quran: Metode 3T+1M, Mudah dan Efektif', unida.gontor.ac.id.

[13] Miles, M. B. and A. M. H. (1992) Analisis Data Kualitatif: Buku Sumber Tentang Metode-Metode Baru. Jakarta: UI Press.

[14] Wahid, W. A. (2014) Cara Cepat Bisa Menghafal Al-Qur'an. Jogjakarta: DIVA press.

[15] Wahyu Eko Hariyanti (2019) Metode Menghafal Al Qur'an Pada Anak Usia Dini (Studi Kasus Di TKIT Yaa Bunayya and RA Darussalam Yogyakarta. UIN Sunan Kalijaga.

[16]Zahra, D. N. (2019) 'Development of Islamic Education Curriculum Model Curriculum 2013 (K13)', AL-HAYAT: Journal of Islamic Education, 3(1), pp. 3852. doi: 10.35723/ajie.v3i1.50. 